\title{
Selected 3-hydroxy-3-methyl-glutaryl-coenzyme A reductase inhibitors. A look into their use and potential in pre-diabetes and type 2 diabetes
}

\author{
Douglas Edward BArre, Kazimiera Amelia Mizier-Barre \\ Department of Health Sciences, Cape Breton University, Sydney, Nova Scotia, Canada \\ E-mail:ed_barre@cbu.ca
}

\begin{abstract}
Objectives. This review assesses the comparative safety and efficacy of selected 3-hydroxy-3methylglutaric acid coenzyme A inhibitors (statins, cinnamic acids. 3-hydroxy-3-methyl glutaric acid) on the pre-onset type 2 diabetes (PT2D) and post-onset type 2 diabetes (T2D)-related cluster of seven features (central obesity, hyperglycemia, hypertension, dyslipidemia, pro-thrombosis, oxidation and inflammation).

Methods. Google scholar and PubMed were searched for statin*, flaxseed lignan complex (FLC), cinnamic acid (CA)*, and 3-hydroxy-3-methylglutaric acid (HMGA) in conjunction with each of PT2D, T2D and the cluster of seven. An introduction was followed by findings or absence thereof on the impacts of each of statins, FLC, CAs and HMGA on each member of the cluster of seven.

Results. Pravastatin manages three features in PT2D, while a number of the statins improve five in T2D. FLC is negative in PT2D but controls four in T2D; it is not clear if the CAs and HMGA in FLC play a role in this success. CAs have potential in six and HMGA has potential in three of the cluster of seven though yet CAs and HMGA are untested in PT2D and T2D in humans. There are safety concerns with some statins and HMGA but FLC and CAs appear safe in the doses and durations tested.

Conclusions. Selected statins, FLC, CAs and HMGA can manage or have a potential to manage at least three features of the cluster of seven. Most of the literature-stated concerns are with select statins but there are concerns (one actual and two potential) with HMGA.
\end{abstract}

Key words: statins, flaxseed lignan complex, cinnamic acids, 3-hydroxy-3-methylglutaric acid, 3-hydroxy-3-methylglutaric acid coenzyme A reductase inhibition, type 2 diabetes mellitus, central obesity, hyperglycemia, hypertension, dyslipidemia, pro-thrombosis, oxidation and inflammation

A cluster of seven features (central obesity, hyperglycemia, hypertension, dyslipidemia, pro-thrombosis, oxidation and inflammation) in whole or in part is associated with pre-type 2 diabetes (PT2D) or type 2 diabetes (T2D). Each member of the cluster contributes to atherosclerosis and its sequelae, myocardial infarction and stroke, the two major causes of death in T2D patients (Sasaki et al. 1995; Alberti et al. 2007; Sharma et al. 2017). This paper was prompted by findings that 3-hydroxy-3-methylglutarate coenzyme A reductase inhibitors (HMG-
CoA RIs) (statins; cinnamic acids, CAs; 3-hydroxy-3methyl-glutaric acid, HMGA) (Di Padova et al. 1982; Istvan and Deisenhofer 2001; Lee et al. 2007; Prabhakar and Doble 2011; Sirtori 2014) have the ability or potential ability to manage a number of members of the cluster of seven as does flaxseed lignan complex (FLC) (Peterson et al. 2010; Prasad et al. 2020) containing CAs and HMGA (Muir 2006). FLC also contains secoisolariciresinol diglucoside (SDG), but there is no evidence that it or its mammalian derived lignans, enterodiol and enterolactone, are HMG-CoA

Corresponding author: Dr. D. E. Barre, Department of Health Sciences, Cape Breton University, Sydney, Nova Scotia, Canada, B1P 6L2; phone: 902-563-1921; fax: 902-563-1945; e-mail: ed_barre@cbu.ca. 
RIs and so their effects (Barre and Mizier-Barre 2020) are not mediated by HMG-CoA R inhibition. Consequently, the focus of this paper will be on FLC, CAs and HMGA compared to statins, the most commonly prescribed HMG-CoA RIs.

\section{Central obesity}

Central obesity is a frequent pre-cursor of PT2D and T2D. There are no reports indicating that any of the statins reduces or manages central obesity. Atorvastatin dose (20 vs. $40 \mathrm{mg} /$ day) (Maksymets et al. 2019) does not decrease waist circumference in obese non-diabetic patients. However, FLC (600 mg SDG/day) (Barre et al. 2012) very modestly decreased waist circumference gain over a three-month period in older T2D patients. What if anything CA and/or HMGA in FLC had to do with the modest decrease in waist circumference gain is not clear. There are no reports CAs or HMGA managing central obesity in PT2D or T2D but in high fat diet induced-obese rats, CA caused reduced weight gain (Mnafgui et al. 2015). Yousufzai and Siddiqi (1977) found that HMGA reduced triglyceride in epididymal fat and caused less weight gain in rats fed an atherogenic diet. While it appears that there is nothing published on CAs and HMGA central adiposity management in humans, it would be of interest to see the results of such investigations.

\section{Hyperglycemia}

Pravastatin increased insulin sensitivity, lowered fasting plasma glucose and HbAlc after 10 weeks on $20 \mathrm{mg}$ q.d. at bedtime in those with metabolic syndrome, and hence it was hypothesized that Pravastatin may manage metabolic syndrome so as to reduce their risk of T2D (Guclu et al. 2004; Yamagishi et al. 2006). However, Maksymets et al. (2019) showed higher insulin resistance and fasting plasma glucose at 40 vs. $20 \mathrm{mg} /$ day Atorvastatin in obese nondiabetic persons. Similarly, Jula et al. (2002) suggested the possibility of heightened insulin resistance with Simvastatin in hypercholesterolemic non-diabetic men. Thus, dose and structure-function relationships are consistent with the poorer glycemic control in T2D patients on Atorvastatin but not Pitavastatin and Pravastatin (Yamakawa et al. 2008). Pitavastatin improves glycemic control in T2D patients (Cui et al 2018). Cornish et al. (2009) observed no change in fasting serum glucose as the result of FLC consumption in non-diabetic persons with metabolic syndrome. Barre et al. (2012) noted an FLC induced decrease in fasting plasma glucose in older T2D patients. It must be pointed out that the plasma glucose decrease described by Barre et al. (2012) is not necessarily due to HMG-CoA $\mathrm{R}$ inhibition via CAs and/or HMGA as FLC also contains SDG, albeit not an HMG-CoA RI; as well other CA- or HMGAinduced mechanisms may be at play. For example, HMG-CoA expression is reduced by CA in differentiated 3T3-L1 adipocytes and CA improves 2-dideoxyglucose uptake into those cells (Prabhakar and Doble 2011). Whether CA caused improved 2-dideoxyglucose uptake via reduced HMG-CoA expression is not clear. As well, CA lowered hepatic HMG-CoA activity in high cholesterol fed healthy rats (Lee et al. 2007) but no reference was made in that paper to glucose, and it is not clear from the literature if hyperglycemia management can result from HMG-CoA $\mathrm{R}$ inhibition. CA decreased fasting blood glucose in $\mathrm{db} / \mathrm{db}$ T2D model mice (Yoo et al. 2012) and in nonobese T2D rats (Cicero and Colletti 2016), decreased serum glucose in alloxan-induced T2D rats (Wang et al. 2015) and improved glucose tolerance in vivo in streptozotocin-induced T2D rats (Hafizur et al. 2015). HMGA lowered fasting plasma glucose in healthy male mice (Witherup et al. 1995). Interestingly, HMGA aciduria (Hammond and Wilckhen 1984) and HMG-CoA lyase deficiency (Douillard et al. 2012) are associated with hypoglycemia in humans (Wysocki et al. 1976; Duran et al. 1978); HMGA aciduria is caused by HMG-CoA lyase deficiency (Fernandes et al. 2016) and HMGA inhibits HMG-CoA lyase (Witherup et al. 1995). An HMGA containing flavonoid glucoside chamaemeloside improved glucose tolerance and fasting plasma glucose in healthy mice perhaps due to the HMGA moiety release in vivo from the chamaemeloside causing HMG CoA lyase inhibition and making the chamaemeloside a prodrug (Konig et al. 1998). Konig et al. (1998) speculated that the improved fasting plasma glucose could have been due to lowered gluconeogenesis with improved glucose tolerance arising from decreased intestinal glucose absorption and increased hepatic and peripheral glucose disposal but the role, if any, of HMGA on those factors is not clear from that paper.

\section{Hypertension}

Guclu et al. (2004) demonstrated a drop in both systolic and diastolic pressures in female metabolic syndrome patients taking Pravastatin $(20 \mathrm{mg} / \mathrm{day}$, 10 weeks), suggesting that meant a lower risk for T2D development; however, the mean pre-treatment diastolic pressure was not hypertensive. Maksymets 
et al. (2019) reported that obese but non-diabetic patients did not have lower systolic and diastolic pressures on 40 vs. $20 \mathrm{mg} /$ day Atorvastatin but a greater percentage of those on the higher dose fell below the $140 / 90$ target. On a speculative note, Atorvastatin thus may have contributed to the higher percentage of those falling below the 140/90 target (Maksymets et al. 2019). As well Wang et al. (2013) indicated that Simvistatin can increase the vasodilatory nitric oxide in the serum of coronary heart disease complicated congestive heart failure patients. FLC had no impact on lowering systolic or diastolic pressures (Barre et al. 2012) in older T2D patients but Cornish et al. (2009) observed a decrease in diastolic pressure as the result of FLC consumption in persons with metabolic syndrome. There appear to be no reports of CAs or HMGA preventing or managing hypertension in PT2D or T2D onset in animals or humans. However, it may be that CAs or HMGA, via dyslipidemia management may reduce atherosclerosis and hence manage hypertension in PT2D or T2D.

\section{Dyslipidemia}

Guclu et al. (2004), using Pravastatin in metabolic syndrome patients, showed a drop in total plasma cholesterol, low-density lipoprotein cholesterol (LDLc), and triglycerides with an increase in highdensity lipoprotein cholesterol (HDLc) with Jula et al. (2002) showing the same effects in serum after Simvastatin administration in T2D patients. Scharnagl et al. (2004) noted that Cervivastatin lowered serum total cholesterol, LDLc and small dense (sd)-LDLc in T2D patients with increased sd-LDLc. Sone et al. (2002) did not report serum sd-LDL-c but did show a drop in the proportion of sd-LDL, relative to total LDL, in T2D patients taking Pitavastatin. Ikezaki et al. (2020) have noted the importance of sd-LDLc and LDLc in causing atherosclerotic progression. Atorvastatin, increased plasma LDL size in T2D patients though there was no mention of sd-LDLc (Pontrelli et al. 2002). Increased LDL size proportion reduces atherosclerosis (Hulthe et al. 2000). However, Barre et al. (2012) did not show a change in plasma sd LDLc in older T2D patients consuming FLC; that said, the cholesterol content of sd-LDL may not be tied to the relative proportion of sd-LDL particles to total LDL particles. Cornish et al. (2009) observed no change in fasting serum total cholesterol, triglycerides, the total cholesterol:HDLc ratio, HDLc or LDLc as the result of FLC consumption in persons with metabolic syndrome. FLC consumption was without impact on any aspect of dyslipidemia (Pan et al. 2007; Barre et al. 2012) in T2D, though in the case of Barre et al. (2012), patients were not hypercholesterolemic while those in the Pan et al. (2007) study were hypercholesterolemic; it could be that the CA and/or HMGA dose/length of time given was insufficient to alter the identified lipids. However, plasma cholesterol and LDLc lowering has been observed (Zhang et al. 2008), in non-diabetic hypercholesterolemic persons consuming FLC though the contribution of CAs or HMGA to cholesterol lowering has not been elucidated in FLC consumers. Hallund et al. (2006) looked at FLC administered to healthy post-menopausal females with normal lipid blood serum levels and found no change in HDLc, LDLc, cholesterol and triglycerides. CA decreased plasma cholesterol, LDLc and triglycerides and increased plasma HDLc in $\mathrm{db} / \mathrm{db}$ mice (Yoo et al. 2012) and decreased serum cholesterol and triglycerides in alloxan-induced T2D rats (Wang et al. 2015). Thus, again, CAs or HMGA, if given in sufficient dose and length of time, may be hypercholesterolemic/antidyslipidemic agents (Prasad 1999, 2005; Yoo et al. 2012; Wang et al. 2015). As HMG-CoA R is the rate limiting enzyme in cholesterol synthesis, its inhibition very effectively decreases cholesterol synthesis as demonstrated in rat hepatic tissue (in vitro) (Beg and Lupien 1972) and hence lowers hepatic cholesterol as demonstrated in rats (in vivo) (Beg et al. 1968) and serum cholesterol in rats (Beg and Siddiqi 1968) and as such may contribute to lowering plasma cholesterol in some FLC consumers. Indeed, Lupien et al. (1979) found that $2250 \mathrm{mg}$ of HMGA/day for 8 weeks in heterozygous familial hypercholesterolemia patients significantly lowered plasma cholesterol and LDLc with no effect on triglycerides though these patients had not been diagnosed with PT2D or T2D. Lupien et al. (1978) observed a decrease in plasma cholesterol in one non-diabetic homozygous familial hypercholesterolemic patient taking 1500 and 3000 $\mathrm{mg}$ of HMGA/day combined with diet therapy for an undisclosed time period. Lupien et al. (1973a) found decreases in serum cholesterol three patients with Frederickson type II hyperlipoproteinemia patients taking HMGA. There was no mention of inability to tolerate HMGA, side effects or contraindications in the Lupien et al. (1973a,b, 1978, 1979) studies except for transient elevations of serum triglycerides in 2 of 3 patients reported by Lupien et al. (1973a); elevated triglycerides can be a problem as they increase atherosclerotic risk (Hsueh and Law 1998) in PT2D and T2D due to such elevation causing decreased increased sd-LDLc (Nikolic et al. 2013; Hirano 2018) and decreased HDLc (Calabresi et al. 1990) as well as the risk of developing T2D (Tirosh et al.. 2008). Thus, 
Table 1

Impact of selected 3-hydroxy-3-methyl-glutaryl-coenzyme A reductase inhibitors on the cluster of seven ${ }^{1}$

\begin{tabular}{|c|c|c|c|c|c|c|c|}
\hline $\begin{array}{l}\text { Nature } \\
\text { of Study }\end{array}$ & $\begin{array}{l}\text { Central } \\
\text { Obesity }\end{array}$ & Hyperglycemia & Hypertension & Dyslipidemia & Pro-thrombosis & Oxidation & Inflammation \\
\hline $\begin{array}{l}\text { Human } \\
\text { PT2D }\end{array}$ & $\begin{array}{l}\text { Statins } \\
\text { FLC } \\
\text { CAs } \\
\text { HMGA }\end{array}$ & $\begin{array}{l}\text { Statins-yes } \\
\text { Pravastatin }^{6} \\
\text { FLC-negative } \\
\text { CAs } \\
\text { HMGA }\end{array}$ & $\begin{array}{l}\text { Statins-yes } \\
\text { Pravastatin }^{6,17} \\
\text { FLC-yes- } \\
\text { diastolic } \\
\text { CAs } \\
\text { HMGA }\end{array}$ & $\begin{array}{l}\text { Statins-yes } \\
\text { Pravastatin }^{6,17} \\
\text { FLC-negative } \\
\text { CAs } \\
\text { HMGA }\end{array}$ & $\begin{array}{l}\text { Statins } \\
\text { FLC } \\
\text { CAs } \\
\text { HMGA }\end{array}$ & $\begin{array}{l}\text { Statins } \\
\text { FLC } \\
\text { CAs } \\
\text { HMGA }\end{array}$ & $\begin{array}{l}\text { Statins } \\
\text { FLC } \\
\text { CAs } \\
\text { HMGA }\end{array}$ \\
\hline Human T2D & $\begin{array}{l}\text { Statins } \\
\text { FLC-yes } \\
\text { CAs } \\
\text { HMGA }\end{array}$ & $\begin{array}{l}\text { Statins } \\
\text { Atorvastatin } \\
\text { worsens } \\
\text { Pitavastatin } \\
\text { improves } \\
\text { Pravastatin no } \\
\text { adverse effect }^{8,9} \\
\text { FLC-yes }{ }^{2} \\
\text { CAs } \\
\text { HMGA }\end{array}$ & $\begin{array}{l}\text { Statins } \\
\text { FLC-negative }{ }^{2} \\
\text { CAs } \\
\text { HMGA }\end{array}$ & $\begin{array}{l}\text { Statins-yes } \\
\text { Cervivastatin } \\
\text { Pitavastatin } \\
\text { Atorvastatin } \\
\text { Simvistatin } \\
10,18,19 \\
\text { FLC-negative } e^{2,20} \\
\text { CAs } \\
\text { HMGA }\end{array}$ & $\begin{array}{l}\text { Statins-yes but } \\
\text { Simvistatin } \\
\text { may increase } \\
\text { thrombosis }^{33,34} \\
\text { FLC-yes } \\
\text { CAs } \\
\text { HMGA }\end{array}$ & $\begin{array}{l}\text { Statins-yes }^{37} \\
\text { FLC- } \\
\text { negative } \\
\text { CAs } \\
\text { HMGA }\end{array}$ & $\begin{array}{l}\text { Statins-yes }{ }^{41-43} \\
\text { Atorvastatin } \\
\text { and } \\
\text { Simvistatin }^{44,45} \\
\text { FLC-yes }{ }^{2,46} \\
\text { CAs } \\
\text { HMGA }\end{array}$ \\
\hline $\begin{array}{l}\text { Human non- } \\
\text { PT2D or } \\
\text { non-T2D }\end{array}$ & $\begin{array}{l}\text { Statins } \\
\text { negative }^{3} \\
\text { FLC } \\
\text { CAs } \\
\text { HMGA }\end{array}$ & $\begin{array}{l}\text { Statins } \\
\text { Atorvastin and } \\
\text { Simvistatin } \\
\text { worsen } \\
\text { FLC } \\
\text { CAs } \\
\text { HMGA }\end{array}$ & $\begin{array}{l}\text { Statins } \\
\text { Atorvastatin }{ }^{9} \\
\text { FLC } \\
\text { CAs } \\
\text { HMGA }\end{array}$ & $\begin{array}{l}\text { Statins-yes } \\
\text { FLC-positive }{ }^{21} \\
\text { and negative } \\
\text { results } \\
\text { CAs } \\
\text { HMGA-yes } \text { H-23-28 }^{22}\end{array}$ & $\begin{array}{l}\text { Statins } \\
\text { FLC } \\
\text { CAs-yes-in } \\
\text { vitro }^{35} \\
\text { HMGA }\end{array}$ & $\begin{array}{l}\text { Statins-yes } \\
\text { Simvistatin } \\
\text { may lower } \\
\text { antioxidant } \\
\text { potential }{ }^{10} \\
\text { FLC } \\
\text { CAs } \\
\text { HMGA }\end{array}$ & $\begin{array}{l}\text { Statins yes }{ }^{43} \\
\text { FLC yes }{ }^{77} \\
\text { CAs } \\
\text { HMGA }\end{array}$ \\
\hline $\begin{array}{l}\text { Animal } \\
\text { PT2D }\end{array}$ & $\begin{array}{l}\text { Statins } \\
\text { FLC } \\
\text { CAs } \\
\text { HMGA }\end{array}$ & $\begin{array}{l}\text { Statins } \\
\text { FLC } \\
\text { CAs } \\
\text { HMGA }\end{array}$ & $\begin{array}{l}\text { Statins } \\
\text { FLC } \\
\text { CAs } \\
\text { HMGA }\end{array}$ & $\begin{array}{l}\text { Statins } \\
\text { FLC } \\
\text { CAs } \\
\text { HMGA }\end{array}$ & $\begin{array}{l}\text { Statins } \\
\text { FLC } \\
\text { CAs } \\
\text { HMGA }\end{array}$ & $\begin{array}{l}\text { Statins } \\
\text { FLC } \\
\text { CAs } \\
\text { HMGA }\end{array}$ & $\begin{array}{l}\text { Statins } \\
\text { FLC } \\
\text { CAs } \\
\text { HMGA }\end{array}$ \\
\hline $\begin{array}{l}\text { Animal T2D } \\
\text { model }\end{array}$ & $\begin{array}{l}\text { Statins } \\
\text { FLC } \\
\text { CAs } \\
\text { HMGA }\end{array}$ & $\begin{array}{l}\text { Statins } \\
\text { FLC } \\
\text { CAs-yes }{ }^{11-14} \\
\text { HMGA }\end{array}$ & $\begin{array}{l}\text { Statins } \\
\text { FLC } \\
\text { CAs } \\
\text { HMGA }\end{array}$ & $\begin{array}{l}\text { Statins } \\
\text { FLC } \\
\text { CAs-yes }{ }^{11,13} \\
\text { HMGA-yes }^{29}\end{array}$ & $\begin{array}{l}\text { Statins } \\
\text { FLC } \\
\text { CAs } \\
\text { HMGA }\end{array}$ & $\begin{array}{l}\text { Statins } \\
\text { FLC } \\
\text { CAs } \\
\text { HMGA }\end{array}$ & $\begin{array}{l}\text { Statins } \\
\text { FLC } \\
\text { CAs } \\
\text { HMGA }\end{array}$ \\
\hline $\begin{array}{l}\text { Animal non- } \\
\text { pre- or post- } \\
\text { onset T2D }\end{array}$ & $\begin{array}{l}\text { Statins } \\
\text { FLC } \\
\text { CAs yes } \\
\text { HMGA-yes }^{5}\end{array}$ & $\begin{array}{l}\text { Statins } \\
\text { FLC } \\
\text { CAs } \\
\text { HMGA-yes }^{15}\end{array}$ & $\begin{array}{l}\text { Statins } \\
\text { FLC } \\
\text { CAs } \\
\text { HMGA }\end{array}$ & $\begin{array}{l}\text { Statins } \\
\text { FLC } \\
\text { CAs } \\
\text { HMGA-yes }{ }^{30-32}\end{array}$ & $\begin{array}{l}\text { Statins } \\
\text { FLC } \\
\text { CAs-yes-in } \\
\text { vitro }^{36} \\
\text { HMGA }\end{array}$ & $\begin{array}{l}\text { Statins } \\
\text { FLC } \\
\text { CAs-yes } \\
\text { HMGA- } \\
\text { may reduce } \\
\text { antioxidant } \\
\text { potential }^{39}\end{array}$ & $\begin{array}{l}\text { Statins } \\
\text { Simvastatin } \\
\text { Pravastatin } \\
\text { Rouvastatin }{ }^{48,49} \\
\text { FLC } \\
\text { CAs-yes }{ }^{50} \\
\text { HMGA }\end{array}$ \\
\hline Cell culture & $\begin{array}{l}\text { Statins } \\
\text { FLC } \\
\text { CAs } \\
\text { HMGA }\end{array}$ & $\begin{array}{l}\text { Statins } \\
\text { FLC } \\
\text { CAs-yes }{ }^{16} \\
\text { HMGA }\end{array}$ & $\begin{array}{l}\text { Statins } \\
\text { FLC } \\
\text { CAs } \\
\text { HMGA }\end{array}$ & $\begin{array}{l}\text { Statins } \\
\text { FLC } \\
\text { CAs } \\
\text { HMGA }\end{array}$ & $\begin{array}{l}\text { Statins } \\
\text { FLC } \\
\text { CAs } \\
\text { HMGA }\end{array}$ & $\begin{array}{l}\text { Statins } \\
\text { Pravastatin } \\
\text { FLC } \\
\text { CAs } \\
\text { HMGA }\end{array}$ & $\begin{array}{l}\text { Statins } \\
\text { FLC } \\
\text { CAs } \\
\text { HMGA }\end{array}$ \\
\hline
\end{tabular}

Abbreviations: CAs - cinnamic acids; FLC - flaxseed lignan complex; HMGA - 3-hydroxy-3-methyl-glutaric acid; PT2D - pre-onset type 2 diabetes; T2D - type 2 diabetes. 'blank beside statins, FLC, CA, or HMGA means no studies found; otherwise yes (for beneficial findings) or negative findings are noted; ${ }^{2}$ Barre et al. 2012; ${ }^{3}$ Maksymets et al. 2019; ${ }^{4}$ Mnafgui et al. $2015 ;{ }^{5}$ Yousufzai and Siddiqi 1977; ${ }^{6}$ Yamagishi et al. 2006; ${ }^{7}$ Cornish et al 2009; ${ }^{8}$ Yamakawa et al. 2008; ${ }^{9}$ Cui et al. 2018; ${ }^{10}$ Jula et al. 2002; ${ }^{11}$ Yoo et al. 2012; ${ }^{12}$ Cicero and Colletti 2016; ${ }^{13}$ Wang et al. 2015; ${ }^{14}$ Hafizur et al. 2015; ${ }^{15}$ Witherup et al. 1995; ${ }^{16}$ Prabhakar and Doble $2011 ;{ }^{17}$ Guclu et al. 2004; ${ }^{18}$ Scharnagl et al. 2004; ${ }^{19}$ Pontrelli et al. 2002; ${ }^{20} \mathrm{Pan}$ et al. 2007; ${ }^{21}$ Zhang et al. 2008; ${ }^{22}$ Hallund et al. 2006; ${ }^{23} \mathrm{Beg}$ et al. $1968 ;{ }^{24} \mathrm{Beg}$ and Siddiqi 1968; ${ }^{25}$ Lupien et al. 1973a; ${ }^{26}$ Lupien et al. 1973b; ${ }^{27}$ Lupien et al. 1978; ${ }^{28}$ Lupien et al. $1979 ;{ }^{29}$ Francesconi et al. 1987; ${ }^{30}$ Yousufzai and Siddiqi 1976a; ${ }^{31}$ Kahn et al. 1972; ${ }^{32}$ Yusufi and Siddiqi 1974; ${ }^{33}$ Perego and Davi 2012; ${ }^{34}$ Postula et al. 2012; ${ }^{35} \mathrm{Hubbard}$ et al. 2003; ${ }^{36} \mathrm{Kim}$ et al. 2010; ${ }^{37}$ Ohara et al. 2018; ${ }^{38}$ Lee et al. $2007 ;{ }^{39}$ Frank et al. 2004; ${ }^{40} \mathrm{Ceolotto}$ et al. 2006; ${ }^{41}$ Lodovici et al. 2015; ${ }^{42}$ Schonbeck and Libby 2004; ${ }^{43}$ Paradela-Dobarra et al. 2013; ${ }^{44}$ Milajerdi et al. 2020; ${ }^{45}$ Lee et al. 2002; ${ }^{46}$ Pan et al. 2009; ${ }^{47}$ Hallund et al. 2008; ${ }^{48}$ Sukhova et al. 2002; ${ }^{49}$ Kim et al. 2019; ${ }^{50}$ Anlar et al. 2018. 
caution with HMGA must be noted though transiency of elevated triglycerides may not be an issue. However, there are no other reports of HMGA-driven elevated triglycerides so the two patients may not be representative of a larger patient population. In streptozotocin-diabetic rats, HMGA did not significantly increase plasma HDLc though there was a trend toward an increase in such (they also noted a significant decrease in plasma cholesterol and triglycerides as the result of HMGA administration) (Francesconi et al. 1987). HMGA lowered serum total triglyceride and cholesterol and cholesterol and triglyceride in serum $\beta$-lipoproteins in Triton WR-1339 induced hyperlipidemia in rats Yousufzai and Siddiqi (1976a). Khan et al. (1972) observed a HMGA-induced lowering of serum cholesterol in non-diabetic rabbits fed an atherogenic diet. Yusufi and Siddiqi (1974) found that HMGA lowered serum and aortic cholesterol and triglycerides in non-diabetic, hyperlipemic male albino rabbits. Consistent with such findings was the observation that HMGA could shrink atherosclerotic lesions in male albino rabbits (Lupien et al. 1973b); unfortunately, such work appears not to have been done in humans. As well, Yousufzai and Siddiqi (1976b) observed aortic arch atheromatous lesion regression in non-diabetic rats as the result of HMGA administration. Such atherosclerosis management is important as atherosclerosis causes myocardial infarction and stroke the two major causes of death in T2D patients (Sasaki et al. 1995; Alberti et al. 2007; Sharma et al. 2017).

\section{Pro-thrombosis}

The statins can reduce thrombosis (via reduced inflammation) in T2D patients (Perego and Davi 2012) with Wang et al. (2013) pointing that Simvistatin can increase the plasma levels of antiplatelet aggregatory nitric oxide in non-T2D humans. Despite that finding, Isley et al. 2006 have cautioned that Simvastatin can increase mean platelet volume in T2D patients, such being a potentially contributing factor to increased thrombosis. Postula et al. (2012) have also suggested that statins can reduce platelet reactivity in T2D patients. Barre et al. (2012) showed an increased bleeding time, indicative of decreased platelet aggregability and hence pro-thrombosis, due to FLC consumption in older T2D patients. CA inhibits healthy rat (Kim et al. 2010) and healthy human (Hubbard et al. 2003) in vitro platelet aggregation. However, there is no direct evidence of impact or lack thereof of CAs or HMGA on elevated platelet reactivity in PT2D or T2D patients.

\section{Oxidation}

Rosenson (2004), in a review paper, demonstrated the LDL antioxidant capacity of statin drugs. As well Ohara et al. (2018) noted less oxidative stress with statin use in T2D patients. Ceolotto et al. (2006) demonstrated in ex vivo fibroblasts that Pravastatin could reduce insulin-induced free radicals. As oxidation leads to inflammation (Lodovici et al. 2015; Hussain et al. 2016), it is possible to hypothesize that Pravastatin might do the same in PT2D and T2D. However, Jula et al. (2002) found lower plasma total peroxyl radical-trapping antioxidant potential and increased conjugated diene formation as the result of Simvastatin administration in hypercholesterolemic males. Barre et al. (2012) failed to show a drop in LDL oxidation when FLC was consumed by older T2D patients. This may be a case of inhibitor type (CAs or HMGA) and/or dose and/or duration of treatment not being sufficient to result in lower LDL oxidation. However, CA lowered hepatic malondialdehyde and elevated erythrocyte and hepatic catalase, glutathione peroxidase and elevated erythrocyte glutathione in high cholesterol fed rats (Lee et al. 2007). HMGA appears not to have been studied in terms of oxidation but as it, like the statins, are HMG-CoA RIs and as least some statins lower oxidation (Ohara et al. 2018), HMGA too may lower oxidation, albeit perhaps independent of such inhibition. However, in rats, SDG oligomers with HMGA lowered $a$-tocopherol and the combination of $\alpha$-tocopherol and $\gamma$-tocopherol in plasma more so than SDG alone (Frank et al. 2004) so caution in using HMGA as an antioxidant is warranted. As well, Fernandes et al. $(2013,2016)$ found an increase in oxidative stress due to an HMG-CoA lyase deficiency causing elevated HMGA in rat brain tissue, so caution may be warranted in those with such a deficiency. There appears to be no direct evidence of impact of CAs or HMGA on oxidation in PT2D and/or T2D patients. However, individuals who do not adequately clear HMG-CoA due to an HMG-CoA lyase deficiency (Jones et al. 2020) experience increased oxidative stress (dos Santos Mello et al. 2015; da Rosa et al. 2016; Vamecq et al. 2020). In these persons, concomitant consumption of bezafibrate may reduce oxidation (da Rosa-Junior et al. 2020). As well, HMGA is largely metabolized in the kidney and excess plasma levels of HMGA may be an indicator of early-stage renal dysfunction (Nierenberg et al. 2019) so again HMGA would not be appropriate for such individuals with an HMG-CoA lyase deficiency. 


\section{Inflammation}

Milajerdi et al. (2020), in a review paper indicated that Atorvastatin and Simvistatin in T2D patients could decrease the generalized inflammatory marker (serum C-reactive protein, CRP) with Atorvastatin possibly reducing serum interleukin-6 (IL-6), the principal inducer of the CRP gene (Volanakis 2001). As well, Lee et al. (2002) noted that Simvistatin induced a decrease in plasma CRP levels in T2D patients. Lodovici et al. (2015) indicated that T2D females but not males with complications responded to statin treatment with a lowering of inflammation as measured by decreased plasma CRP. ParadelaDobarro et al. (2013) indicated that unspecified statins use lowered serum high sensitivity (HS)-CRP in study pool of patients with and without T2D.

Diamantis et al. (2017), in a review paper, noted that the anti-inflammatory aspects of some statins can improve the prognosis for coronary artery disease in human including those with post-onset T2D. Schonbeck and Libby (2004) indicated that the statins have an anti-inflammatory role, dependent and independent of statin-induced lipid lowering, but they did not mention PT2D or T2D. Sukhova et al. (2002) noted that Simvastatin and Pravastatin inhibit inflammation in the atheroma of adult male nondiabetic cynomolgus monkeys. Atorvastatin and Rouvastatin influenced the gut's microbiota composition which correlated with decreased ileal proinflammatory interleukin-1 $\beta$ (IL-1 $\beta$ ) and increased ileal anti-inflammatory transforming growth factor $1 \beta$ (TGF-1 $\beta$ ) expression in high fat diet fed C57BL/6N mice (an aged mouse model) (Kim et al. 2019). FLC better managed plasma CRP in healthy post-menopausal women (Hallund et al. 2008) and serum CRP compared to controls in T2D patients (Pan et al. 2009) and reduced plasma CRP in older T2D patients (Barre et al. 2012) but the role of CAs and HMGA contained in FLC is not clear. CA may have antiinflammatory potential as Anlar et al. (2018) reported it to be an antioxidant in T1D rats. There is nothing in the literature about the use of HMGA to combat inflammation.

\section{Some words of caution regarding certain HMG-CoA RIs}

Words of caution are in order in that, controversially (Mogadam 2014; Skoumas et al. 2018), some of the statins have been suggested in some papers increase the incidence of T2D in patients at risk of that pathology (Macedo et al. 2014; Gastaldi and
Philippe 2015; Climent et al. 2017; Li et al. 2018). Indeed, Barkas et al. (2020) noted that the greatest risk of statin-caused $\mathrm{T} 2 \mathrm{D}$ is in the metabolically unhealthy obese and metabolically unhealthy nonobese patients with statin treated metabolically healthy obese not being at risk of T2D; however, the metabolically healthy obese can, in a non-statin related manner become metabolically unhealthy (Kouvari et al. 2019), and so caution with statin use must be exhibited in those moving toward a metabolically unhealthy state even though such is not statin-related. Jick and Bradbury (2004) indicated that Pravastatin and Simvistatin do not protect against the development of T2D but gave no indication that those two drugs conferred a greater degree of risk of developing T2D. Jeong et al. (2019) have data to suggest that Pitavastatin may not be of concern in increasing T2D risk but may cause increased calorie and fat consumption (Sugiyama et al. 2014). Riche and McClendon (2007) have indicated that use of statins in T2D patients should be individualized if there is no pre-existing cardiovascular disease and that statins should not be used solely because the patient has T2D. There are, as of yet, no words of caution to date regarding FLC or CAs. There are some concerns with HMGA. Toxic levels of HMGA occur in persons with HMG-CoA lyase deficiency and there is one report of elevated triglycerides in two non-diabetic persons on HMGA. As well, HMGA may lower plasma a-tocopherol and the combination of $\alpha$-tocopherol and $\gamma$-tocopherol and thus possibly reducing anti-oxidant potential.

\section{Conclusion}

PT2D and T2D patients require management of the cluster of seven (central obesity, hyperglycemia, hypertension, dyslipidemia, pro-thrombosis, oxidation and inflammation). Studies suggest that selected HMG-CoA RIs (statins, FLC with CAs and HMGA and each of CAs and HMGA) alone and/or in combination have or may have the potential to influence at least three members of the cluster of seven. The potential for pleiotropic effects of selected statins (hyperglycemia, hypertension and dyslipidemia in PT2D and hyperglycemia, dyslipidemia, pro-thrombosis, oxidation and inflammation in T2D), FLC (central obesity, hyperglycemia, pro-thrombosis and inflammation in T2D), CAs (hyperglycemia and dyslipidemia-animal model T2D only and in non-PT2D and non T2D animals, obesity, hyperglycemia, pro-thrombosis and oxidation) and HMGA (obesity, hyperglycemia and dyslipidemia in non-PT2D or non-T2D animals and 
dyslipidemia in non-PT2D or non-T2D humans) may not be solely centered on their HMG-CoA R inhibition ability. However, in PT2D and T2D patients, large scale multi-center clinical trials with short-term and long-term agent exposure analysis for various doses, are lacking to establish their full safety and efficacy in management of the members of the cluster of seven, as demonstrated by in vivo mechanisms by one or more of these agents. Some of the statins and HMGA have some real and/or potential safety concerns. However, contraindications, side effects and drug interactions have yet to be fully established for all the aforementioned HMG-CoA RIs in PT2D and T2D humans. Table 1 summarises this paper.

\section{References}

Alberti KG, Zimmet P, Shaw J. International Diabetes Federation: a consensus on T2D prevention. Diabet Med 24, $451-463,2007$

Anlar HG, Bacanli M, Cal T, Aydin S, Ari N, Undeger Bucurgat U, Basaran AA, Basaran AN. Turk. Effects of cinnamic acid on complications of diabetes. J Med Sci 48, 168-177, 2018.

Barkas F, Liamis G, Elisaf M, Anastasiou G, Liberopoulos E. Metabolically healthy obesity and risk of incident T2D in 1077 statin-treated individuals: A six-year retrospective study. Eur J Prev Cardiol 27, 2341-2344, 2020.

Barre DE, Mizier-Barre KA, Stelmach E, Hobson J, Griscti O, Rudiuk A, Muthuthevar D. Flaxseed lignan complex administration in older human T2D patients manages central obesity and prothrombosis - an invitation to further investigation into polypharmacy reduction. J Nutr Metab 2012, 585170, 2012.

Barre DE, Mizier-Barre KA. Lignans' potential in pre- and post-onset type 2 diabetes management. Curr Diabetes Rev 16, 2-11, 2020.

Beg ZH, Siddiqi M. Effect of 3-hydroxy-3-methylglutaric acid on blood lipids in normal and cholesterol-fed rats. Experientia 24, 791-792, 1968.

Beg ZH, Siddiqu M, Siddiqi RA. Effect of 3-hydroxy-3-methylglutaric acid on hypercholesterolemic liver. Experientia 24, 15-16, 1968.

Beg ZH, Lupien PJ. In vitro and in vivo inhibition of hepatic cholesterol synthesis by 3-hydroxy-3-methylglutaric acid. Biochim Biophys Acta 260, 439-448, 1972.

Calabresi L, Franceschini G, Sirtori M, Gianfranceschi G, Werba P, Sirtori CR. Influence of serum triglycerides on the HDL pattern in normal subjects and patients with coronary artery disease. Atherosclerosis 84, 41-48, 1990.

Ceolotto G, Papparella I, Lenzini L, Sartori M, Mazzoni M, Iori E, Franco L, Gallo A, de Kreutzenberg SV, Tiengo A, Pessina AC, Avogaro A, Semplicini A. Insulin generates free radicals in human fibroblasts ex vivo by a protein kinase C-dependent mechanism, which is inhibited by pravastatin. Free Radic Biol Med 41, 473-83, 2006.

Cicero AF, Colletti A. Role of phytochemicals in the management of metabolic syndrome. Phytomedicine 23, $1134-$ 1144, 2016.

Climent E, Perez-Calahorra S, Marco-Benedi V, Plana N, Sanchez R, Ros E, Ascaso JF, Puzo J, Almagro F, Lahoz C, Civeira F, Pedro-Botet. Effect of LDL cholesterol, statins and presence of mutations on the prevalence of T2D in heterozygous familial hypercholesterolemia. J. Sci Rep 7, 5596, 2017.

Cornish SM, Chilibeck PD, Paus-Jennsen L, Biem HJ, Khozani T, Senanayake V, Vatanparast H, Little JP, Whiting SJ, Pahwa P. A randomized controlled trial of the effects of flaxseed lignan complex on metabolic syndrome composite score and bone mineral in older adults. Appl Physiol Nutr Metab 34, 89-98, 2009.

Cui JY, Zhou RR, Han S, Wang TS, Wang LQ, Xie XH. Statin therapy on glycemic control in type 2 diabetic patients: A network meta-analysis. J Clin Pharm Ther 43, 556-570, 2018.

da Rosa MS, Seminotti B, Ribeiro CA, Parmeggiani B, Grings M, Wajner M, Leipnitz G. 3-Hydroxy-3-methylglutaric and 3-methylglutaric acids impair redox status and energy production and transfer in rat heart: relevance for the pathophysiology of cardiac dysfunction in 3-hydroxy-3-methylglutaryl-coenzyme A lyase deficiency. Free Radic Res 50, 997-1010, 2016.

da Rosa-Junior NT, Parmeggiani B, Glanzel NM, de Moura Alvorcem L, Frusciante MR, Dutra Filho CS, Wajner M, Leipnitz G. In vivo evidence that bezafibrate prevents oxidative stress and mitochondrial dysfunction caused by 3-methylglutaric acid in rat liver. Biochimie 171-172, 187-196, 2020.

Di Padova C, Bosisio E, Cighetti G, Rovagnati P, Mazzocchi M, Colombo C, Tritapepe R. 3-Hydroxy-3-methylglutaric acid (HMGA) reduces dietary cholesterol induction of saturated bile in hamster. Life Sci 30, 1907-1914, 1982.

Diamantis E, Kyriakos G, Quiles-Sanchez LV, Farmaki P, Troupis T. The Anti-inflammatory effects of statins on coronary artery disease: An updated review of the literature. Curr Cardiol Rev 13, 209-216, 2017. 
Douillard C, Mention K, Dobbelaere D, Wemeau JL, Saudubray JM, Vantyghem MC. Hypoglycaemia related to inherited metabolic diseases in adults. Orphanet J Rare Dis 7, 26, 2012.

Dos Santos Mello M, Ribas GS, Wayhs CA, Hammerschmidt T, Guerreiro GB, Favenzani JL, Sitta A, de Moura Coelho D, Wajner M, Vargas CR. Increased oxidative stress in patients with 3-hydroxy-3-methylglutaric aciduria. Mol Cell Biochem 402, 149-155, 2015.

Duran M, Ketting D, Wadman SK, Jakobs C, Schutgens RB, Veder HA. Organic acid excretion in a patient with 3-hydroxy-3-methylglutaryl-CoA deficiency: facts and artefacts. Clin Chim Acta 90, 187-193, 1978.

Fernandes CG, da Rosa MS, Seminotti B, Pierozan P, Martell RW, Lagranha VL, Busanello EN, Leipnitz G, Wajner $M$. In vivo experimental evidence that the major metabolites accumulating in 3-hydroxy-3-methylglutarylCoA lyase deficiency induce oxidative stress in striatum of developing rats: a potential pathophysiological mechanism of striatal damage in this disorder. Mol Genet Metab 109, 144-153, 2013.

Fernandes CG, Rodrigues MDN, Seminotti B, Colin-Gonzalez AL, Santamaria A, Quincozes-Santos A, Wajner M. Induction of a proinflammatory response in cortical astrocytes by the major metabolites accumulating in HMG-CoA lyase deficiency: the role of ERK signaling pathway in cytokine release. Mol Neurobiol 53, 35863595, 2016.

Francesconi M, Galzigna L, Plebani M, Furlanetto V, Fabris R, Deana R. Effect of 3-hydroxy-3-methylglutarate treatment on plasma ketone bodies, triglycerides, and HDL-cholesterol in streptozotocin-diabetic rats. Clin Biochem 20, 201-205, 1987.

Frank J, Eliasson C, Leroy-Nivard D, Budek A, Lundh T, Vessby B, Aman P, Kamal-Eldin A. Dietary secoisolariciresinol diglucoside and its oligomers with 3-hydroxy-3-methyl glutaric acid decrease vitamin E levels in rats. Brit J Nutr 92, 169-176, 2004.

Gastaldi G, Philippe J. Statins and diabetes: The plot thickens. J Gen Intern Med 30, 1572-1573, 2015.

Guclu F, Ozmen B, Hekimsoy Z, Kirmaz C. Effects of a statin group drug, pravastatin, on the insulin resistance in patients with metabolic syndrome. Biomed Pharmacother 58, 614-618, 2004.

Hafizur RM, Hameed A, Shukrana M, Raza SA, Chishti S, Kabir N, Siddiqui RA Cinnamic acid exerts anti-diabetic activity by improving glucose tolerance in vivo and by stimulating insulin secretion in vitro. Phytomed 22, 297-300, 2015.

Hallund J, Ravn-Haren G, Bugel S, Tholstrup T, Tetens I. A lignan complex isolated from flaxseed does not affect plasma lipid concentrations or antioxidant capacity in healthy postmenopausal women. J Nutr 136, 112-116, 2006.

Hallund J, Tetens I, Bugel S, Tholstrup T, Bruun JM. The effect of a lignan complex isolated from flaxseed on inflammation markers in healthy postmenopausal women. Nutr Metab Cardiovasc Dis 18, 497-502, 2008.

Hammond J, Wilcken B. 3-hydroxy-3-methylglutaric, 3-methylglutaconic and 3-methylglutaric acids can be nonspecific indicators of metabolic disease. J Inherit Metab Dis 7 Suppl 2, 117-118, 1984.

Hirano T. Pathophysiology of diabetic dyslipidemia. J Atheroscler Thromb 25, 771-782, 2018.

Hsueh WA, Law RE. Cardiovascular risk continuum: implications of insulin resistance and diabetes. Am J Med 105, 4S-14S, 1998.

Hubbard GP, Wolffram S, Lovegrove JA, Gibbins JM. The role of polyphenolic compounds in the diet as inhibitors of platelet function. Proc Nutr Soc 62, 469-478, 2003.

Hulthe J, Bokemark L, Wikstrand J, Fagerberg B. The metabolic syndrome, LDL particle size, and atherosclerosis: the Atherosclerosis and Insulin Resistance (AIR) study. Arterioscler Thromb Vasc Biol 20, 2140-2147, 2000.

Hussain T, Tan B, Yin Y, Blachier F, Tossou MC, Rahu N. Oxidative stress and inflammation: What polyphenols can do for us? Oxid Med Cell Longev 2016, 7432797, 2016.

Ikezaki H, Furusyo N, Yokota Y, Ai M, Asztalos BF, Murata M, Hayashi J, Schaefer EJ. Small dense low-density lipoprotein cholesterol and carotid intimal medial thickness progression. J Atheroscler Thromb 27, 1108-1122, 2020.

Isley WL, Park Y, Harris WS. The effect of high dose simvastatin on, platelet size in patients with, T2D mellitus. Platelets 17, 292-295, 2006.

Istvan ES, Deisenhofer J. Structural mechanism for statin inhibition of HMG-CoA reductase. Science 292, 11601164, 2001.

Jeong HS, Hong SJ, Son S, An H, Kook H, Joo HJ, Park JH, Yu CW, Lim DS. Incidence of new-onset diabetes with 1 $\mathrm{mg}$ versus $4 \mathrm{mg}$ pitavastatin in patients at high risk of developing diabetes during a 3-year follow-up. Cardiovasc Diabetol 18, 162, 2019.

Jick SS, Bradbury BD. Statins and newly diagnosed diabetes. Br J Clin Pharmacol 58, 303-309, 2004.

Jones DE, Perez L, Ryan RO. 3-Methylglutaric acid in energy metabolism. Clin Chim Acta 502, 233-239, 2020. 
Jula A, Marniemi J, Huupponen R, Virtanen A, Rastas M, Ronnemaa T. Effects of diet and simvastatin on serum lipids, insulin, and antioxidants in hypercholesterolemic men: a randomized controlled trial. JAMA 287, $598-605,2002$.

Khan AN, Umar S, Khan SY, Siddiqi M. Hypocholesterolaemic and hypolipidaemic role of 3-hydroxy-3-methylglutarate in rabbits fed on an atherogenic diet. Biochem J 128, 41P-42P, 1972.

Kim SY, Koo YK, Koo JY, Ngoc TM, Kang SS, Bae K, Kim YS, Yun-Choi HS. Platelet anti-aggregation activities of compounds from Cinnamomum cassia. J Med Food 13, 1069-1074, 2010.

Kim J, Lee H, An J, Song Y, Lee CK, Kim K, Kong H. Alterations in gut microbiota by statin therapy and possible intermediate effects on hyperglycemia and hyperlipidemia. Front Microbiol 10, 1947, 2019.

Konig GM, Wright AD, Keller WJ, Judd RL, Bates S, Day C. Hypoglycaemic activity of an HMG-containing flavonoid glucoside, chamaemeloside, from Chamaemelum nobile. Planta Med 64, 612-614, 1998.

Kouvari M, Panagiotakos DB, Yannakoulia M, Georgousopoulou E, Critselis E, Chrysohoou C, Tousoulis D, Pitsavos C; ATTICA Study Investigators. Transition from metabolically benign to metabolically unhealthy obesity and 10-year cardiovascular disease incidence: The ATTICA cohort study. Metabolism 93, 18-24, 2019.

Lee IT, Sheu WH, Lin SY, Lee WJ, Song YM, Liu HC. Simvastatin reduces plasma concentration of high-sensitivity Creactive protein in type 2 diabetic patients with hyperlipidemia. J Diabetes Complications 16, 382-385, 2002.

Lee MK, Park YB, Moon SS, Bok SH, Kim DJ, Ha TY, Jeong TS, Jeong KS, Choi MS. Hypocholesterolemic and antioxidant properties of 3-(4-hydroxyl) propanoic acid derivatives in high-cholesterol fed rats. Chem Biol Interact 170, 9-19, 2007.

Li H, Lin H, Zhao H, Xu Y, Cheng Y, Shen P, Zhan S. Statins use and risk of new-onset diabetes in hypertensive patients: a population-based retrospective cohort study in Yinzhou district, Ningbo city, People's Republic of China. Ther Clin Risk Manag 14, 823-832, 2018.

Lodovici M, Bigagli E, Luceri C, Mannucci E, Rotella CM, Raimondi L Gender-related drug effect on several markers of oxidation stress in diabetes patients with and without complications. Eur J Pharmacol 766, 86-90, 2015.

Lupien PJ, Brun D, Moorjani S. Effectiveness of 3-hydroxy-3-methylglutaric acid in familial hypercholesterolaemia. Lancet 1(7814), 1256, 1973a.

Lupien PJ, Tremblay M, Beg ZH. 3-Hydroxy-3-methylglutaric acid: protective action in experimental atherosclerosis in rabbits. Atherosclerosis 18, 407-416, 1973b.

Lupien PJ, Brun D, Moorjani S. Long-term treatment of homozygous familial hypercholesterolaemia with 3-hydroxy3-methylglutaric acid. Lancet 1(8058), 283-284, 1978.

Lupien PJ, Moorjani S, Brun D, Bielmann I. Effects of 3-hydroxy-3-methylglutaric acid on plasma and low-density lipoprotein cholesterol levels in familial hypercholesterolemia. J Clin Pharmacol 19, 120-126, 1979.

Macedo AF, Douglas I, Smeeth L, Forbes H, Ebrahim S Statins and the risk of T2D mellitus: cohort study using the UK clinical practice research datalink. BMC Cardiovasc Disord 14, 85, 2014.

Maksymets T, Sorochka M, Bondarenko O, Karpyshyn N, Bochar O, Sklyarov Y. Comparison of metabolic profile of obese non-diabetic patients with coronary artery disease depending on atorvastatin dose. Wiad Lek. 272, 846-850, 2019.

Milajerdi A, Sadeghi A, Mousavi SM, Larijani B, Esmaillzadeh A. Influence of statins on circulating inflammatory cytokines in patients with abnormal glucose homeostasis: a meta-analysis of data from randomized controlled trials. Clin Ther 42, e13-e31, 2020.

Mnafgui K, Derbali A, Sayadi S, Gharsallah N, Elfeki A, Allouche N. Anti-obesity and cardioprotective effects of cinnamic acid in high fat diet-induced obese rats. J Food Sci Technol 52, 4369-4377, 2015.

Mogadam M. Do statins increase the risk of diabetes or is it guilt by association? Curr Opin Endocrinol Diabetes Obes 21, 140-145, 2014.

Muir AD. Flax lignans--analytical methods and how they influence our understanding of biological activity. J AOAC Int 89, 1147-1157, 2006.

Nierenberg JL, He J, Li C, Gu X, Shi M, Razavi AC, Mi X, Li S, Bazzano LA, Anderson AH, He H, Chen W, Kinchen JM, Rebholz CM, Coresh J, Levey AS, Inker LA, Shlipak M, Kelly TN. Novel associations between blood metabolites and kidney function among Bogalusa Heart Study and Multi-Ethnic Study of Atherosclerosis participants. Metabolomics 15, 149, 2019.

Nikolic D, Katsiki N, Montalto G, Isenovic ER, Mikhailidis DP, Rizzo M. Lipoprotein subfractions in metabolic syndrome and obesity: clinical significance and therapeutic approaches. Nutrients 5, 928-948, 2013.

Ohara M, Nagaike H, Goto S, Fukase A, Tanabe Y, Tomoyasu M, Yamamoto T, Hayashi T, Fukui T, Hirano T. Improvements of ambient hyperglycemia and glycemic variability are associated with reduction in oxidative stress for patients with T2D. Diabetes Res Clin Pract 139, 253-261, 2018. 
Pan A, Sun J, Chen Y, Ye X, Li H, Yu Z, Wang Y, Gu W, Zhang X, Chen X, Demark-Wahnefried W, Liu Y, Lin X. Effects of a flaxseed-derived lignan supplement in type 2 diabetic patients: a randomized, double-blind, crossover trial. PLoS One 2, el148, 2007.

Pan A, Demark-Wahnefried W, Ye X, Yu Z, Li H, Qi Q, Sun J, Chen Y, Chen X, Liu Y, Lin X. Effects of a flaxseed-derived lignan supplement on C-reactive protein, IL- 6 and retinol-binding protein 4 in type 2 diabetic patients. Br J Nutr 101, 1145-1149, 2009.

Paradela-Dobarro B, Raposeiras-Roubin S, Rodino-Janeiro BK, Grigorian-Shamagian L, Garcia-Acuna JM, AguiarSouto P, Jacquet-Hervet M, Reino-Maceiras MV, Gonzalez-Juanatey JR, Alvarez E. Statins modulate feedback regulation mechanisms between advanced glycation end-products and C-reactive protein: evidence in patients with acute myocardial infarction. Eur J Pharm Sci, 49, 512-518, 2013.

Perego F, Davi G. Beyond hyperglycemia in diabetes: role of statin treatment on thrombogenesis triggered by inflammation: Editorial to: "Impact of statins on the coagulation status of T2D patients evaluated by a novel thrombin-generations assay" by P. Ferroni et al. Cardiovasc Drugs Ther 26, 281-284, 2012.

Peterson J, Dwyer J, Adlercreutz H, Scalbert A, Jacques P, McCullough ML. Dietary lignans: physiology and potential for cardiovascular disease risk reduction. Nutr Rev 68, 571-603, 2010.

Pontrelli L, Parris W, Adeli K, Cheung RC. Atorvastatin treatment beneficially alters the lipoprotein profile and increases low-density lipoprotein particle diameter in patients with combined dyslipidemia and impaired fasting glucose/T2D. Metabolism 51, 334-342, 2002.

Postula M, Rosiak M, Kaplon-Cieslicka A, Kondracka A, Trzepla E, Filipiak KJ, Czlonkowski A, Opolski G. Do statins influence platelet reactivity on acetylsalicylic acid therapy in patients with T2D? Cardiol J 19, 494-500, 2012.

Prabhakar PK, Doble M. Interaction of cinnamic acid derivatives with commercial hypoglycemic drugs on 2-deoxyglucose uptake in 3T3-L1 adipocytes. J Agric Food Chem 59, 9835-9844, 2011.

Prasad K. Reduction of serum cholesterol and hypercholesterolemic atherosclerosis in rabbits by secoisolariciresinol diglucoside isolated from flaxseed. Circulation 99, 1355-1362, 1999.

Prasad K. Hypocholesterolemic and antiatherosclerotic effect of flaxseed lignan complex isolated from flaxseed. Atherosclerosis 179, 269-275, 2005.

Prasad K, Khan AS, Shoker M. Flaxseed and its components in treatment of hyperlipidemia and cardiovascular disease. Int J Angiol 29, 216-222, 2020.

Riche DM, McClendon KS. Role of statins for the primary prevention of cardiovascular disease in patients with T2D mellitus. Am J Health Syst Pharm 64, 1603-1610, 2007.

Rosenson RS. Statins in atherosclerosis: lipid-lowering agents with antioxidant capabilities. Atherosclerosis 173, $1-12,2004$.

Sasaki A, Horiuchi N, Hasegawa K, Uehara M. Mortality from coronary heart disease and cerebrovascular disease and associated risk factors in diabetic patients in Osaka District, Japan. Diabetes Res Clin Pract 27, 77-83, 1995.

Scharnagl H, Winkler K, Mantz S, Baumstark MW, Wieland H, Marz W. Inhibition of HMG-CoA reductase with cerivastatin lowers dense low density lipoproteins in patients with elevated fasting glucose, impaired glucose tolerance and T2D mellitus. Exp Clin Endocrinol Diabetes 112, 269-277, 2004.

Sharma A, Green JB, Dunning A, Lokhnygina Y, Al-Khatib SM, Lopes RD, Buse JB, Lachin JM, Van de Werf F, Armstrong PW, Kaufman KD, Standl E, Chan JCN, Distiller LA, Scott R, Peterson ED, Holman RR; TECOS Study Group. Causes of death in a contemporary cohort of patients with type 2 diabetes and atherosclerotic cardiovascular disease: Insights from the TECOS Trial. Diabetes Care 40, 1763-1770, 2017.

Schonbeck U, Libby P. Inflammation, immunity, and HMG-CoA reductase inhibitors: statins as antiinflammatory agents? Circulation 109, 18-26, 2004.

Sirtori CR. The pharmacology of statins. Pharmacol Res 88, 3-11, 2014.

Skoumas I, Masoura C, Aznaouridis K, Metaxa V, Tsokanis A, Papadimitriou L, Tousoulis D, Pitsavos C, Stefanadis C. Impact of cardiometabolic risk factors on major cardiovascular events in patients with familial combined hyperlipidemia. Circ J. 77, 163-168, 2018.

Sone H, Takahashi A, Shimano H, Ishibashi S, Yoshino G, Morisaki N, Saito Y, Kawazu S, Teramoto T, Fujita T, Shiba T, Iwamoto Y, Kuzuya N, Akanuma Y, Yamada N. HMG-CoA reductase inhibitor decreases small dense low-density lipoprotein and remnant-like particle cholesterol in patients with type-2 diabetes. Life Sciences 71, 2403-2412, 2002.

Sugiyama T, Tsugawa Y, Tseng CH, Kobayashi Y, Shapiro MF. Different time trends of caloric and fat intake between statin users and nonusers among US adults: gluttony in the time of statins? JAMA Intern Med, 174, 1038-1045, 2014. 
Sukhova GK, Williams JK, Libby P. Statins reduce inflammation in atheroma of nonhuman primates independent of effects on serum cholesterol. Arterioscler Thromb Vasc Biol 22, 1452-1458, 2002.

Tirosh A, Shai I, Bitzur R, Kochba I, Tekes-Manova D, Israeli E, Shochat T, Rudich A. Changes in triglyceride levels over time and risk of T2D in young men. Diabetes Care 31, 2032-2037, 2008.

Vamecq J, Papegay B, Nuyens V, Boogaerts J, Leo O, Kruys V. Mitochondrial dysfunction, AMPK activation and peroxisomal metabolism: A coherent scenario for non-canonical 3-methylglutaconic acidurias. Biochimie $168,53-82,2020$.

Volanakis JE. Human C-reactive protein: expression, structure, and function. Mol Immunol 38, 189-197, 2001.

Wang H, Li Q, Deng W, Omari-Siaw E, Wang Q, Wang S, Wang S, Cao X, Xu X, Yu J. Self-nanoemulsifying drug delivery system of trans-cinnamic acid, formulation development and pharmacodynamic evaluation in alloxan-induced type 2 diabetic rat model. Drug Develop Res 76, 82-93, 2015.

Wang L, Shi J, Zhang Y. Influences of simvastatin on vascular endothelial function of patients with coronary heart disease complicated with congestive heart failure. Eur Rev Med Pharmacol Sci 17, 1590-1593, 2013.

Witherup KM, McLaughlin JL, Judd RL, Ziegler MH, Medon PJ, Keller WJ. Identification of 3-hydroxy-3-methylglutaric acid (HMG) as a hypoglycemic principle of Spanish moss (Tillandsia usneoides). J Nat Prod 58, 1285-1290, 1995.

Wysocki SJ, Wilkinson SP, Hahnel R, Wong CY, Panegyres PK. 3-Hydroxy-3-methylglutaric aciduria, combined with 3-methylglutaconic aciduria. Clin Chim Acta 70, 399-406, 1976.

Yamagishi S, Matsui T, Sato T, Takeuchi M. Protective role of pravastatin in the pathogenesis of the metabolic syndrome. Med Hypotheses 66, 609-611, 2006.

Yamakawa T, Takano T, Tanaka S, Kadonosono K, Terauchi Y. Influence of pitavastatin on glucose tolerance in patients with T2D mellitus. J Atheroscler Thromb 15, 269-275, 2008.

Yoo KM, Lee C, Lo YM, Moon B. The hypoglycemic effects of American red ginseng (Panax quinquefolius L.) on a diabetic mouse model. J Food Sci 77, H147-H152, 2012.

Yousufzai SY, Siddiqi M. 3-Hydroxy-3-methylglutaric acid and triton-induced hyperlipidemia in rats. Experientia 32, 1178-1179, 1976a.

Yousufzai SY, Siddiqi M. 3-hydroxy-3-methylglutaric acid and experimental atherosclerosis in rats. Experientia 32, 1033-1034, 1976b.

Yousufzai SY, Siddiqi M. Tissue lipid responses to 3-hydroxy-3-methylglutaric acid with different dietary fats. Lipids 12, 258-261, 1977.

Yusufi AN, Siddiqi M. Studies on the hypolipidemic and hypocholesterolemic effect of 3-hydroxy-3-methylglutaric acid in rabbits. Atherosclerosis 20, 517-526, 1974.

Zhang W, Wang X, Liu Y, Tian H, Flickinger B, Empie MW, Sun SZ. Dietary flaxseed lignan extract lowers plasma cholesterol and glucose concentrations in hypercholesterolaemic subjects. Br J Nutr 99, 1301-1309, 2008. 